\title{
DAS PRÁTICAS TRADICIONAIS ÀS PRÁTICAS REDUCIONAIS: RITUAIS DE CURA, LUTO E SEPULTAMENTO NAS REDUÇÕES JESUÍTICO-GUARANI (PROVÍNCIA JESUÍTICA DO PARAGUAI, SÉCULO XVII) ${ }^{1}$
}

\author{
ELIANE CRISTINA DECKMANN FLECK ${ }^{2}$ \\ UNISINOS
}

\begin{abstract}
RESUMO: Este artigo se propõe a evidenciar e analisar o impacto das concepções cristãs de doença e de morte na sensibilidade indígena guarani e sua tradução em termos de representações e práticas sociais nas reduções jesuíticas. A análise dos registros feitos pelos missionários, sobretudo das Cartas Ânuas da Província Jesuítica do Paraguai referentes ao período de 1609 a 1675, revelou que, por um lado, os Guarani mantiveram práticas tradicionais de sua sensibilidade religiosa - como fica evidenciado na ressignificação do "chorar copioso" e dos lamentos fúnebres -, e, por outro, que os missionários, além de incorporarem a farmacopéia americana e muitas das práticas curativas indígenas, manipularam habilmente as curas e o "bien morir", estratégia que foi fundamental para o êxito do projeto de civilização-conversão da Companhia de Jesus junto aos Guarani.
\end{abstract}

PALAVRAS-CHAVE: doença; morte; sensibilidade religiosa; ressignificação; reduções jesuítico-guarani.

ABSTRACT: This article intends to evince and analyze the impact of the Christian conceptions of sickness and death on the Guarani indian sensibility and its translation in terms of representations and social practices in the Jesuitical reductions. The analysis of the records made by the missionaries, especially the Cartas Anuas of the Jesuitical Province of Paraguay regarding the period from 1609 to 1675, revealed that, on the one hand, the Guarani kept traditional practices of their religious sensibility - as is evinced in the resignification of the "copious crying" and the funereal laments -, and, on the other hand, that the missionaries, besides incorporating the native pharmacopoeia and many of the indian healing practices, skillfully manipulated the cures and the "bien morir", a strategy that was fundamental to the success of the civilization-conversion project of the Companhia de Jesus alongside the Guarani.

\footnotetext{
${ }^{1}$ Uma versão preliminar deste artigo foi apresentada na Mesa Redonda "A morte nas fronteiras culturais", no IV Congresso Latino-americano de Ciências Sociais e Humanidades, que ocorreu na Universidade Salgado de Oliveira, em Niterói, Rio de Janeiro, de 27/07 a 29/07/2010.

2 Doutora em História pela Pontifícia Universidade Católica do Rio Grande do Sul (PUCRS), pesquisadora do CNPq e integrante do Grupo de Pesquisa "Jesuítas nas Américas", é atualmente professora e pesquisadora do Curso de Graduação e do Programa de Pós-Graduação em História da Universidade do Vale do Rio dos Sinos (UNISINOS). Dentre os capítulos de livros e artigos publicados, destacam-se os que contemplam suas investigações sobre as missões religiosas na América lusoespanhola e sobre os processos decorrentes do contato interétnico e intercultural, com ênfase na análise das expressões de religiosidade e dos saberes e práticas de cura. E-mail: ecdfleck@terra.com.br .
} 
KEYWORDS: sickness; death; religious sensibility; resignification; Jesuitical-Guarani reductions.

\section{À guisa de introdução}

Nas Cartas Ânuas ${ }^{3}$ da Província Jesuítica do Paraguai ${ }^{4}$, sobretudo no período compreendido entre as décadas de 30 e 50 do século XVII, as epidemias - e as mortes que a elas se seguiam - merecem lugar de destaque, na medida em que eram percebidas tanto como fatores responsáveis pelo fracasso da ação missionária entre os indígenas guarani quanto como predisponentes às manifestações de devoção e de piedade dos indígenas nas reduções jesuíticas ${ }^{5}$. Além de registrar os efeitos das epidemias nas nascentes comunidades, os missionários jesuítas dedicaram-se também a descrever - e a condenar - a farmacopeia nativa e os procedimentos de cura adotados pelos xamãs guarani, bem como a destacar as curas milagrosas - e as conversões delas resultantes - que ocorriam nas reduções.

Para a análise que pretendemos fazer desta documentação, consideraremos que estes rituais de cura não poderão ser pensados fora das superstições que formavam o maravilhoso e das "tendências gerais da consciência coletiva" da época em questão, uma vez que isso implicaria condená-los antecipadamente e, principalmente, percebê-los "apenas como uma anomalia ridícula" (BLOCH, 1993, p. 171).

\section{Sobre enfermidades e rituais de cura}

\footnotetext{
${ }^{3}$ Em relação às Cartas Ânuas deve-se observar que as Litterae Anuae são a correspondência periódica que os Padres Provinciais enviavam ao Padre Geral da Companhia de Jesus. Elas têm sua base nos relatórios anuais que o Provincial recebia dos superiores das Residências, Colégios, Universidades e Missões junto aos índios. Continham uma detalhada informação sobre as casas, suas obras, pessoas e atividades. As Cartas Ânuas relativas à Província Jesuítica do Paraguai cobrem o período que vai de 1609 a 1675 e, após um intervalo de cerca de 40 anos, o período de 1714 a 1762.

${ }^{4}$ A antiga Província do Paraguay abrangia, na época colonial, limites bastante mais extensos que os da moderna República Paraguaia. Recebendo o nome do rio que a banhava, compreendia uma imensa região que se estendia entre o Brasil e o Peru até o Rio da Prata e o Oceano Atlântico.

${ }^{5} \mathrm{O}$ termo redução (reducción) foi empregado na América em três acepções, significando, em alguns casos, o processo de congregar índios infiéis em povoados, o próprio povoado e, ainda, o conjunto de povoados considerados unitariamente por razões geográficas ou missionais.
} 
DOSSIÊ: FONTES E PROBLEMAS COLONIAIS, LEITURAS E ANÁLISES ATUAIS:

TEMAS DA CULTURA SUL-AMERÍNDIA NO CONTEXTO COLONIAL

Se, para os povos primitivos, estar enfermo significa "estar poseído o dominado por espíritus animales telúricos, que roban o destruyen al individuo, su alma, o su órgano enfermo"; ser "dueño del remedio" ou "controlador de los espíritus malignos" implica deter o verdadeiro poder mágico e religioso $(\operatorname{VARA}(\mathrm{H}), 1984$, p. 97). Sabe-se que entre os indígenas guarani, o xamã - enquanto detentor deste saber - é percebido como um ser temível, capaz de realizar feitiços e de destruir seus inimigos a léguas de distância, "y la amenaza de ser víctima de ellos está constantemente en la mente Guarani” (VARA $(H)$, 1984, p. 98). Foi nestes feiticeiros, ou então nos xamãs, que os missionários

encontraram os mais sérios obstáculos à cristianização $[\ldots]$ os seus piores $[\ldots]$ mais formidáveis inimigos, porque neles reconheciam - da mesma forma que os índios - um poder obscuro, mas muito real: em suma, eram eles os autênticos sequazes de Satanás (CLASTRES, 1975, p. 35-36).

A crença nos feiticeiros "enterradores" foi registrada pelos missionários jesuítas:

Os piores e mais perniciosos [...] cujo ofício é matar, enterrando eles na casa de quem se deseja matar, algumas sobras de sua comida, cascas de fruta e pedaços de carvão, etc. Às vezes enterram sapos atravessados com alguma espinha de peixe: com que vai enfraquecendo aquele que querem matar, e este, sem outro acidente, morre (MONTOYA, 1985, p. 54$55)^{6}$.

Dessa descrição depreende-se que, para os guaranis, as enfermidades podiam estar ligadas à intrusão de um corpo estranho no organismo, a um malefício enviado por um inimigo/feiticeiro ou, ainda, a infrações do código moral:

\footnotetext{
${ }^{6} \mathrm{O}$ registro selecionado é de Antônio Ruiz de Montoya, que nasceu em Lima, em 13 de junho de 1585, tendo ingressado no noviciado da Companhia de Jesus em 1606. Após sua ordenação, em 1622, foi enviado à Província do Paraguai, cabendo-lhe a administração das reduções do Guairá. Entre 1636 e 1637, foi Superior de todas as Missões da Província Jesuítica do Paraguai. $\mathrm{P}^{\mathrm{e}}$. Montoya é considerado por especialistas no estudo das reduções jesuítico-guarani como o melhor conhecedor da cultura guarani e um dos principais autores para uma etno-história guarani.
} 
DOSSIÊ: FONTES E PROBLEMAS COLONIAIS, LEITURAS E ANÁLISES ATUAIS:

TEMAS DA CULTURA SUL-AMERÍNDIA NO CONTEXTO COLONIAL

El hombre es consciente que todo o existente establecido puede reaccionar a él, cuando ocurren transgresiones del equilibrio de la vivencia; pueden irritarse las deidades, los dueños de animales y naturaleza o ya las almas des-idas de los muertos, infligiendo los 'castigos' de acuerdo a las violaciones socio morales (SUSNIK, 1989, p. 157).

Cabia ao xamã a reversão desses malefícios e, caso se tratasse de feitiçaria, "los gusanos 'extraídos' [do doente] se colocan en un tubo de 'takwara'", que era enterrado "cerca del fuego" para que o seu calor acabasse com a enfermidade e fulminasse "al respectivo hechicero" (SUSNIK, 1989, p. 157). Segundo Alfredo Vara(h), as técnicas curativas xamânicas incluíam “'viajes' imaginarios o alucinatorios, dramatizados por el shamán, repitiendo etapas previamente ejecutadas", que tinham "la finalidad de rescatar el alma del paciente o de interceder por ella ante los dioses o genios celestiales" (VARA(H), 1984, p. 103-104).

Lévi-Strauss (1968), no entanto, observa que não se deve entender "la cura shamánica como una maniobra con un único protagonista", pois "el complejo shamánico se compone de tres protagonistas: enfermo, shamán y comunidad" (LÉVI-STRAUSS, 1968, p. 162-163). Segundo o antropólogo, a eficácia dos rituais reside no consenso de que o xamã cura porque é considerado um grande xamã por todos, logo, o seu poder somente se mantém enquanto "cuenta con la fe y la participación de la comunidad" (LÉVI-STRAUSS, 1968, p. 162).

Em seu estudo sobre a medicina pré-hispânica, Carmen Tellez (1993) remete à uniformidade do tratamento das enfermidades pelos xamãs sul-americanos, já apontada por Alfred Métraux ${ }^{7}$.

Ante el enfermo procedía a hablar con él y con sus familiares para averiguar la causa del mal, después le palpaba todo el cuerpo y procedía a chupar la parte

\footnotetext{
${ }^{7}$ Para Métraux, "Es indudable que gran número de enfermedades e incluso de accidentes debidos a torpeza" eram percebidas pelos indígenas como "manifestaciones de la mala intención del hechicero o de los espíritus; pero no debe deducirse de ello que colocan en el mismo plano todas las afecciones que sufren", isto porque os índios cuidavam "por si mismos las afecciones que consideran como ligeras o se ponen en manos de un curandero - hombre o mujer - que los trata con medios sencillos o con fórmulas mágicas; pero aún se la curación tiene carácter puramente mágico, la actitud del paciente demuestra que no se considera víctima de una fuerza sobrenatural peligrosa" (MÉTRAUX, 1944, p. 157).
} 
DOSSIÊ: FONTES E PROBLEMAS COLONIAIS, LEITURAS E ANÁLISES ATUAIS:

TEMAS DA CULTURA SUL-AMERÍNDIA NO CONTEXTO COLONIAL

lesa para con este ritual extraer el daño. Mediante drogas alucinatorias, se ponía en contacto con los espíritus y pronosticaba el curso de la enfermedad (TÉLLEZ, 1993, p. 110).

A terapêutica guarani, segundo esta historiadora,

estaba basada en el uso de las plantas, algunas con virtudes medicinales, pero todas ellas con propiedades mágicas curativas. Se administraban por vía oral mediante infusiones, o como astringentes y emplastos en picaduras y otros usos tópicos (TÉLLEZ, 1993, p. 110).

Quanto às práticas de caráter preventivo e terapêutico difundidas entre estes indígenas, eram frequentes as escarificações, as cauterizações, a aplicação de ventosas e os emplastros, conforme descrição abaixo:

[...] las escarificaciones hechas en los brazos o en las piernas con objetos punzantes para descongestionar y evitar el cansancio. Ante una picadura ponzoñosa, acercaban la parte lesa al fuego sin llegar a tocarlo, hasta que se adormecía el dolor. También usaban en estas picaduras ventosas hechas con la corteza de calabaza y era tan frecuente su uso que nunca emprendía viaje sin llevar estas ventosas. Los rasguños y pequeños cortes eran tratados con plantas astringentes y de alto contenido en aceites esenciales; en cambio las grandes heridas eran vendadas con tejidos de algodón y a veces tratadas con hojas de tabaco, especialmente si eran heridas gangrenosas (TÉLLEZ, 1993, p. 110).

Ao descrever as práticas curativas guarani, o jesuíta Antônio Ruiz de Montoya destaca o amplo e difundido uso de ervas medicinais e as superstições que cercavam as terapias empregadas pelo xamã:

Usam os índios muitos remédios e ervas (medicinais), que lá a natureza tem produzido. A pedra de São Paulo é de ajuda comprovada; são-no também os alhos esmagados ingeridos o remédio como bebida, a pedra bezoar e outras ervas (medicinais). Mas mais caseiro é o fogo, queimando-se com uma faca em brasa a parte ferida pulverizada com enxofre. É conhecido este remédio e, acudindo-se a tempo, gente picada por tais 
DOSSIÊ: FONTES E PROBLEMAS COLONIAIS, LEITURAS E ANÁLISES ATUAIS: TEMAS DA CULTURA SUL-AMERÍNDIA NO CONTEXTO COLONIAL

cobras está fora de perigo. Os fígados da víbora, sendo ingeridos com alimento, usam-nos como remédio (MONTOYA, 1985, p. 25).

As superstições dos feiticeiros baseiam-se em adivinhações por meio dos cantos das aves: do que inventaram a não poucas fábulas relativas a medicar $\mathrm{e}$ isto com embustes, chupando, por exemplo, ao enfermo, as partes lesadas e tirando o feiticeiro da boca objetos que nela leva ocultos ou escondidos, e mostrando que ele, com sua virtude, Ihe tinha tirado aquilo que lhe causava a doença, assim como uma espinha de peixe, um carvão ou coisa semelhante (MONTOYA, 1985, p. 54).

Descritos ora como sacerdotes do Diabo, ministros do Demônio,

que hacen cosas que espantan y no pueden ser sino por arte del demonio", ora como "oradores natos [que] usan de todo el aparato solemne de gesticulaciones [...] su expresividad y su noble lenguaje [...] otras veces apenas podrán contener la risa ante tanta gravedad fingida (ARROSPIDE, 1997, p. 99-101),

os xamãs detinham poderes como o de falar "con el demonio por medio de la yerba [...] coge[r] las brasas encendidas en las manos sin quemarse y se las comen a bocados, como si fuera cosa muy gustosa y comestible [...]" ou, então, de "abrir un agujero en el techo, por donde había de entrar el mal espíritu, le daban unos desmayos y hacía fieros visajes y meneos[...]" (ARROSPIDE, 1997, p. 99-100). A eficiência do xamã e a eficácia de sua terapêutica foram referidas também pelo historiador argentino Guillermo Furlong (1962), que chega a afirmar que

con anterioridad a la labor misionera entre los Guaraníes, y antes de la venida de los españoles, estos indios eran sanísimos, y como se expresaba un misionero al referirse a ellos, sólo conocían una enfermedad: la vejez (FURLONG, 1962, p. 604) ${ }^{8}$.

\footnotetext{
${ }^{8}$ De acordo com Furlong, os Guarani tinham seus médicos e "medicinas, estribando casi todas estas en el uso de cortezas, semillas, jugos de plantas y árboles de la región" (FURLONG apud ECHENIQUE e FERREIRA., 1985, p. 252). Nora Echenique e Miriam Ferreira referem a utilização de unguentos contra mosquitos e como protetor solar, além das escarificações feitas com "espinas de pescados, aguijones de palmera o dientes de acutí, combatiendo así la pesadez del cuerpo y el cansancio mismo", da "curación ignea" na cauterização de feridas; das ventosas e dos anti-helmínticos, que viriam a ser empregados por toda a população colonial americana (ECHENIQUE e FERREIRA, 1985, p. 252).
} 
DOSSIÊ: FONTES E PROBLEMAS COLONIAIS, LEITURAS E ANÁLISES ATUAIS:

TEMAS DA CULTURA SUL-AMERÍNDIA NO CONTEXTO COLONIAL

\section{Sobre a conversão por obra da "divina justicia"}

As pestes que se abateram sobre os indígenas guarani - e que foram registradas pelos missionários jesuítas nas Cartas Ânuas que analisamos - não puderam ser evitadas e nem eficazmente combatidas, já que os primeiros encontravam-se desprovidos de anticorpos para delas se defenderem. Doenças desconhecidas, como a gripe, sarampo, varíola, tuberculose, febre amarela, malária, pneumonia epidêmica, disenteria, cólera, tifo, sífilis, lepra e doenças venéreas; debilitaram e desorganizaram as populações atingidas, facilitando o avanço da frente espanhola e provocando "además de su hundimiento demográfico, la más total desmoralización del indio” (MELIÁ, 1986, p. 87).

Considerando o imenso território que os Guarani ocupavam no século XVII, as epidemias se propagaram facilmente, devido a sua grande população e à intensa comunicação que existia entre as aldeias, ligadas por uma rede de trilhas e caminhos abertos no interior das florestas ou pelos cursos d'água. Este aspecto pode ser observado na Carta Ânua de 1634, na qual o Pe. Romero atribui a propagação das epidemias ao fato de os Guarani serem "naturalmente andarilhos", sendo que poucos "escapavam de padeçer destas pestes e enfermidades e, assim, uns sucessivamente a outros vão caindo" (ROMERO apud VIANNA, 1970, p. 129)9. Além de nos oferecer a sua interpretação com relação às possíveis causas e natureza das epidemias, o missionário deixa entrever a concepção galênica de doença, ao referir que

[...] têm quase todos as mesmas complexões, as mesmas comidas, e guardar todos ou uma, sem discrepar um mesmo teor de vida, e assim as enfermidades nascidas destes humores $e$

\footnotetext{
${ }^{9}$ Garlet (1997) observa que "os próprios missionários eram, em muitos casos, os agentes transmissores de doenças. Em algumas circunstâncias o efeito das epidemias frustrava as suas expectativas, enquanto que em outras assinava o aval de seu ingresso nas aldeias, sendo tomados por grandes pajés que sabiam como tratar estas novas e estranhas doenças [...]". Por outro lado, "as epidemias, em muitos casos evacuavam as populações nativas de extensas áreas, liberando-as aos colonizadores. Acompanhando o histórico dos contatos entre os antigos Mbyá com a sociedade colonial, fica evidente que os colonos foram se estabelecendo sobre seu território à medida que as doenças produziam verdadeiras clareiras demográficas" (GARLET, 1997, p. 40 - 41).
} 
DOSSIÊ: FONTES E PROBLEMAS COLONIAIS, LEITURAS E ANÁLISES ATUAIS:

TEMAS DA CULTURA SUL-AMERÍNDIA NO CONTEXTO COLONIAL

destemperanças de comidas etc., são as mesmas em todos (ROMERO apud VIANNA, 1970, p. 128-129).

Nessa mesma carta, encontramos a informação sobre como os missionários contornavam a falta de pessoal para o atendimento dos doentes, o que pode ter causado a disseminação das epidemias: “[...] muitas vezes enviamos às aldeias antigas dos índios um mancebo enfermo" (ROMERO apud VIANNA, 1970, p. 112). Isso, sem dúvida, deve ter facilitado, ainda mais, a disseminação das epidemias entre os Guarani, uma vez que não foram evitados os contatos - fruto da ignorância científica da época -, o que teria impedido a contaminação. Não só os padres como os índios contaminados iam continuamente às aldeias que muitas vezes ainda poderiam estar livres das doenças.

As doenças trazidas pelos espanhóis colocaram os Guarani frente a uma necessária reformulação, não somente em termos de percepções, mas também de suas práticas; o que parece ficar evidente tanto no Tesoro de la Lengua Guarani quanto no Bocabulário de la Lengua Guaranio, organizados pelo Pe. Antônio Ruiz de Montoya, e que registram, entre outras, as expressões ligadas às doenças, às epidemias e às reações dos Guarani frente às suas desastrosas consequências. As epidemias, definidas como "peste" ou "enfermedad" pelos jesuítas, foram denominadas pelos Guarani como mbaba, taçi ai, maraa, mbae açi. Entre as doenças epidêmicas destacam-se: tepotí ugui ou tepoti pyta = "camaras de sangre/desinteria"; mbirua = "ampollas/sarampo"; acanundu yrundi ara - naboguara = "quartãns/malária". Como expressões reveladoras da percepção e dos efeitos das epidemias destacamos: nache mo amongueri taci = "a enfermidade levou minha gente"; chembotiabo mbar raci = "a enfermidade acabou com a minha gente"; y pichibi tabaa oupa hacipabamo = "está a aldeia espantada com tantos enfermos"; mbae aci oqui rucu ore rehe = "chove a enfermidade sobre nós" (MONTOYA, 1876).

Apesar de alguns missionários insistirem em atribuir as doenças à "divina justicia", outros entenderam que outras razões podiam provocálas, como a "transmigración y el cambio de clima", que causavam

${ }^{10}$ Cf. Montoya (1876).

Espaço Ameríndio, Porto Alegre, v. 5, n. 2, p. 9-44, out. 2011. 
DOSSIÊ: FONTES E PROBLEMAS COLONIAIS, LEITURAS E ANÁLISES ATUAIS:

TEMAS DA CULTURA SUL-AMERÍNDIA NO CONTEXTO COLONIAL

"frecuentes dolencias en el pueblo"; e que se deveria considerar um outro tipo de intervenção, distinta da magia eclesiástica, como se depreende da referência a que "aplicaron las medicinas del campo de aquella región, pero sin ningún resultado", ou, então, no recrutamento de enfermeiros entre os índios sãos, "para investigar si los había [enfermos] en las casas, campos y selvas" e para denunciar "a antigua superstición de los hechiceros" (apud MAEDER, 1984, p. 88).

As passagens abaixo ilustram o senso de observação prática de alguns missionários, e a relação que estes estabeleceram entre as doenças e as condições de assentamento das populações indígenas. São também frequentes as referências à vinculação entre a "plaga del hambre", a "escasez de sólido alimento" e "toda clase de enfermedades":

[...] tierra pantanosa y llena de lagunas y mosquitos, habiendo padecido por ello muchas enfermedades [...] (PASTELLS, 1912, p. 180).

Desta peste dicen que es causa el rio porque ha crecido supra modum y fuera del curso natural con dos crecientes, que después que iba baxando ya, a su tiempo, torno a crecer otro tanto y mas, y ahora esta in summo sin aber abaxado, $y$ asi ban las enfermedades con el río. Han se visto en el pescados disformes de grandes, sobreaguados muertos, que dicen traían la pestilencia con muchas víboras que cogía la corriente (PASTELLS, 1912, p. 181).

Além de se dedicarem ao criterioso levantamento dos possíveis fatores causadores das epidemias, alguns missionários também registraram - de forma bastante detalhada - o processo de evolução das doenças (o contágio, as tentativas de cura - empíricas ou exorcistas ou então a morte), bem como as principais enfermidades (gripe, disenteria, lepra, sarampo, tifo, varíola) que se abatiam sobre os indígenas reduzidos e os colonos espanhóis instalados nos "pueblos" próximos delas. As passagens que transcrevemos abaixo são ilustrativas não só da preocupação com a evolução do quadro de determinadas doenças, mas também da percepção ocidental de doença evidenciada nas imagens que o missionário constrói sobre o "retrato de la muerte": 
Los aires del mar causaron una epidemia tan atroz que podía uno durar si tenía causas naturales o si era producida por el mismo demonio. Comenzaba la enfermedad con un intolerable dolor de cabeza. Luego torcían se los ojos y perturbábase la razón. Extendía se el mal hacia el cuello, y quitaba la facultad de tragar y hablar. Después salieron úlceras tan feas en la garganta, que inficionaban con su mal olor en tal grado el aliento, que el mismo enfermo parecía ahogarse entre insoportables sufrimientos. En seguida se cubría todo el cuerpo con una erupción semejante a la lepra, y en las entrañas se formaban unos gusanos peludos de asqueroso aspecto, que causaban a los enfermos agudísimos dolores. Al fin se hinchaba horriblemente la cara y reventaba en llagas como paperas. [...] Esta peste postró en menos de ocho días a toda la población a grandes y chicos, hombres y mujeres. Sólo yo y un joven quedamos en pie [...] Adonde me volvía, no veía yo sino oscuras llagas, apostemas destilando pus y gusanos, y en todas partes se me presentaba el retrato de la muerte. Y para cuidar a cuatro mil enfermos quedaba sólo yo con aquel joven. Aconsejáronme algunas personas, sería bueno, sangrar a los dolientes [...] (DOCUMENTOS PARA LA HISTORIA ARGENTINA, tomo XX, 1929, p. 681).

A descrição, sem dúvida, explora amplamente as sensações de dor decorrentes do avanço da doença, e de compaixão e repugnância, através do forte apelo aos sentidos do olfato e da visão. Se homens experimentados e familiarizados com as epidemias na Europa, como os missionários jesuítas, as descreveram com colorações tão realistas, pode-se avaliar o impacto que as epidemias - e seus efeitos - causaram nos indígenas, traumatizando-os e predispondo-os a buscar a salvação da alma na conversão ao Cristianismo ${ }^{11}$.

$\mathrm{Na}$ Ânua de 1637-39, de autoria do Pe. Francisco Lupercio de Zurbano, encontramos a associação entre epidemia e "divina justicia", e, principalmente, entre cura e conversão:

\footnotetext{
${ }^{11}$ É oportuno lembrar que o medo e a desconfiança iniciais por parte dos indígenas foram cedendo diante do "poder de cura" demonstrado pelos missionários frente às doenças desconhecidas e à ineficácia das práticas tradicionais de cura dos karaí nativos. Conforme Garlet, "não era a cura da alma ou do espírito que o demovia a aceitar o missionário, mas a cura dos males físicos" (GARLET, 1997, p. 41).
} 
DOSSIÊ: FONTES E PROBLEMAS COLONIAIS, LEITURAS E ANÁLISES ATUAIS: TEMAS DA CULTURA SUL-AMERÍNDIA NO CONTEXTO COLONIAL

Cuando el hambre estaba en su apogeo en este pueblo, fueron enviados algunos indios de aquí al pueblo de Concepción, para pedir limosna a los Padres un poco de provisiones como alivio en tanta necesidad. [...] el Padre se olvidó añadir a ella algo de carne para ellos. [...] Tres de los indios quisieron tomar venganza del olvido del Padre; agarraron el buey [que estaba pastando], lo mataron y repartieron los cuartos. Ponen algunos de estos últimos en un asador de palo, después de haber comido ya otros cocidos. [...] Pero sucedió que les alcanzó el castigo de Dios. Así como estaban sentados alrededor del fuego, dando vuelta al asador, cayeron de espaldas con sus miembros al aire, y mientras con débil voz rezaban el Padre nuestro y Ave María, se murieron. Los demás quedaron con el susto dos días sin querer comer, y escarmentados en cabeza ajena aprendieron, juntamente, con todo el pueblo, a temer a Dios (ZURBANO apud MAEDER, 1984, p. 125).

No distante ano de 1663, situação similar voltaria a ser referida pelo Provincial Andrés de Rada que, a exemplo do padre Zurbano, sugere que, em termos de explicação para milagres e curas, sempre prevaleça aquela que promove a "reforma de costumbres" dos indígenas e a conversão:

Por el año de 1663 cierto sudor extraño agitó los sentimientos religiosos, tenido por algunos por milagro, por otros por funesto presagio, otros juzgaron de otra manera; pues, esta humedad destilada en gran cantidad de las imágenes, tenida por milagrosa por algunos, la tienen otros por muy natural a cuadros al oleo, atribuyéndole a una descomposición de los ingredientes de la pintura. Yo, por mi parte, no excluiría del todo una intervención de la Providencia, ya que suele producir tal caso un efecto moral, y una saludable reforma de costumbres. Consultado un Padre sobre este caso, explicó que lo mejor sería, arrepentirse de sus pecados, y practicar austeridades corporales, para alejar de nuestras cabezas el flagelo de la divina justicia (RADA apud LEONHARDT, 1927d, p. 103).

O mesmo padre Zurbano, responsável pela Ânua de 1637-39, chegou a considerar a possibilidade de que algumas mortes ocorriam 
DOSSIÊ: FONTES E PROBLEMAS COLONIAIS, LEITURAS E ANÁLISES ATUAIS: TEMAS DA CULTURA SUL-AMERÍNDIA NO CONTEXTO COLONIAL

por razões de ordem natural. Apesar disso, não deixou de ressaltar os seus efeitos na conduta dos indígenas reduzidos:

Algunos de nuestros Padres refirieron este caso de un modo algo diferente. Podía ser que, debilitados por el hambre, comieron de una vez demasiada cantidad de carne, dañándose así su salud y ocasionándose la muerte repentina. Así no hubiera venganza de Dios por el robo cometido, sino efecto natural. A lo menos enseña este ejemplo que la muerte es buena maestra. (ZURBANO apud MAEDER, 1984, p. 125).

A associação entre cura e oferta de alimentos e conversão admitida pelos próprios missionários - é apresentada como determinante para a permanência dos indígenas nas reduções, e para o consequente abandono das antigas práticas.

Valió mucho para que no pereciesen todos la industria del Padre Pedro de Mola, provo a sangrarles y sanaron algunos y así se llenaba todos los días nuestra casa de apestados que acudían ansiosos y deshaldos para que el Padre les diese de comer y les sangrase por sus manos pidiendo todo el pueblo a voces a Nuestro Señor misericordia y muchos por aquel medio la alcanzaron y derramándose por la tierra adentro la fama acudían los gentiles a tropas para que el Padre ejercitase con ellos la misma piedad [...] los cuales no sabiendo como agradecerlos todo el día se andaban tras de el Padre haciéndole mil caricias y afagos y la puerta de casa muchos regocijos y fiestas las noches a su usanza para tenerle contento y los ya cristianos dejándose formar de su doctrina en toda piedad cristiana y cortar lo vicioso y hubo muy señaladas conversiones y los gentiles disponiéndose con gran fervor para el baptismo (CARTA ÂNUA [1632-1634] apud MAEDER, 1990, p. 167).

O empenho em prover os indígenas de alimentos e de garantirIhes a salvação - previsto nas Instruções de Torres Bollo, que orientavam a atuação junto aos indígenas na Província Jesuítica do Paraguai - pode explicar a ênfase dada pelos missionários, em seus relatórios, aos prejuízos que a fome e as epidemias causavam ao projeto reducional, como fica expresso nesta passagem: 
DOSSIÊ: FONTES E PROBLEMAS COLONIAIS, LEITURAS E ANÁLISES ATUAIS:

TEMAS DA CULTURA SUL-AMERÍNDIA NO CONTEXTO COLONIAL

Perecía de hambre el pueblo [...] Los mas delos con esta ocasión desampararon el pueblo, i recurrieron por comida a los sembrados de sus tierras antiguas, donde no había llegado esta plaga, i se vieron los padres en mucho trabajo para hacerlos volver a la reducción porque alegaban se cansaban en sembrar pues los ratones lo destruían todo (DOCUMENTOS PARA LA HISTORIA ARGENTINA, tomo XX, 1929, p. 287).

O comprometimento da conversão dos indígenas fica igualmente visível na interpretação dada à praga de ratos, que expõe a reincidência nas assim denominadas "superstições":

Y casualmente, al tiempo de sembrar, aparecieron enjambres de ratones, nacidos por la sequía, y comenzaron a devastar los campos, por lo cual que algunas víctimas de su superstición lo atribuyeron a brujería (DOCUMENTOS PARA LA HISTORIA ARGENTINA, tomo XX, 1929, p. 591).

Se, por um lado, o retorno aos "sembrados de sus tierras antiguas" prejudicava o trabalho dos missionários, por outro, vinha ao encontro das pregações dos magos, que atribuíam aos padres a responsabilidade pela fome e pelas epidemias, e prometiam a restauração da felicidade perdida aos indígenas:

Mucho trabajo les causó cierto célebre hechicero llamado Yaguacaporo, el cual propaló que era una divinidad, y que se le debía venerar como a dios, aseverando que él había hecho el cielo y la tierra, y que el podía producir buen tiempo y mal tiempo, y que era dueño de vida y muerte (DOCUMENTOS PARA LA HISTORIA ARGENTINA, tomo XX, 1929, p. 556).

\section{Sobre a medicina para o corpo e para a alma}

Se, inicialmente, os missionários negaram a existência de uma farmacopeia nativa, passando a, posteriormente, condená-la, bem como as práticas terapêuticas xamanísticas - qualificadas como demoníacas e mágico-supersticiosas -; em algumas situações bem específicas, eles se 
DOSSIÊ: FONTES E PROBLEMAS COLONIAIS, LEITURAS E ANÁLISES ATUAIS:

TEMAS DA CULTURA SUL-AMERÍNDIA NO CONTEXTO COLONIAL

veriam confrontados com a necessidade de empregar procedimentos curativos que, por preverem a utilização de relíquias, rezas, ervas, sopros e sucções, se assemelhavam muito àquelas que eram alvo de condenação quando executadas pelos xamãs. Isto parece ficar evidente na prática da sucção de ferimentos - ou de partes do corpo do enfermo - que, apesar de condenada quando empregada pelo xamã, assume um caráter piedoso e taumatúrgico ao ser empregada pelo padre:

Un indio sufría una enfermedad muy asquerosa, resistiendo sus apostemas a toda curación. Nuestro Padre, empero, quiso vencer la repugnancia y sanar al enfermo y por eso pensaba que lo mejor sería besar las llagas como si fuesen rosas flagrantes y chuparle la materia infecta [...] (CARTA ÂNUA [1663 - 1666] apud LEONHARDT, 1927d, p. 92).

Registros de curas milagrosas - operadas com o uso de amuletos, relíquias e água benta - são bastante frequentes na documentação jesuítica, evidenciando o largo emprego desta terapêutica pelos missionários, e os efeitos que produziam nos indígenas nas reduções:

Una india de pies a cabeza cubierta de lepra después de bautizarla con la salud del alma se sirvió Nro. Señor comunicarle también la del cuerpo - tienen estos indios particular devoción al agua bendita por las mercedes que nro. Señor por su medio les hace, algunos que han padecido mal de ojos con solo lavarse con esta agua quedaban sanos (CARTA ÂNUA [1616] apud DOCUMENTOS PARA LA HISTORIA ARGENTINA, tomo XX, 1929, p. 28).

Dentre as primeiras cartas produzidas por missionários jesuítas atuantes na Província Jesuítica do Paraguai, destaca-se a do Pe. Marcial de Lorenzana - dirigida ao Provincial Pe. Diego de Torres e datada de 19 de julho de 1610 -, na qual encontramos o registro da prática da impostação das mãos que, mais do que a cura do corpo, promovia a mudança de conduta dos indígenas:

Esta reducción, a "toto genere" va cada día mejor, y los indios y indias se pasan de muy buena gana al asiento nuevo. Después de mi vuelta se han animado 
DOSSIÊ: FONTES E PROBLEMAS COLONIAIS, LEITURAS E ANÁLISES ATUAIS:

TEMAS DA CULTURA SUL-AMERÍNDIA NO CONTEXTO COLONIAL

mucho, y dicen q. han conocido ya el grande amor que les tengo, va acudiendo mas gente, muestran deseo de baptismo, no se nos muere nadie en las enfermedades, los que se han bautizado in "articulo mortis' han sanado, tienen gran devoción con los evangelios y dicen que cuando el $\mathrm{Pe}$. les pone las manos en la cabeza les pone una cura con que ellos sienten q. los sanan; los q. tenían dos mujeres las van dejando y hacen otras cosas en que dan muestras de temer a Dios (LORENZANA apud PASTELLS, 1912, p. 163).

As referências feitas ao uso da "tierra de San Pablo", do "licor de S. Nicolas", do "milagroso sudor" e dos sacramentos do batismo e do viático - em situações que abarcavam desde uma picada de cobra até lepra -, mais do que comprovar a insistência na negação da existência ou da eficácia - das terapêuticas curativas nativas pelos missionários, parecem revelar o esforço que empreenderam para serem médicos dos corpos e das almas dos indígenas:

[...] dos indios viejos que avían sido mordidos de unas víboras tomando tierra-de-San Pablo quedaron sanos, con que se van aficionando a las cosas de nra santa fe [...] (DOCUMENTOS PARA LA HISTORIA ARGENTINA, tomo XX, 1929, p. 98).

A una niña q. estaba muy al cabo bautizo el Pe en los brazos de su me y luego la hizo dar un poquito de licor de S. Nicolás comenzó a mejorar luego y sano en breve [...] otro yndio enfermo de cámaras de sangre estaba tan al cano q apenas se podía cathequizar recibió el sto. baptismo comenzó luego a mejorar sano perfectamte y el miso decía q Dios le había sanado por medio del sto baptismo (DOCUMENTOS PARA LA HISTORIA ARGENTINA, tomo XX, 1929, p. 100).

Aplicó-se el milagroso sudor, y sintió ella alivio, cerrándose el otro día la llaga, de la cual sólo le quedó la cicatriz. La misma escapó por este mismo remedio del inminente peligro de muerte a consecuencia de la peste, pudiendo ya el día siguiente, sana y buena, irse para dar las gracias a su protectora. En una, palabra, este remedio sirvió para toda clase de enfermedades, no sólo del cuerpo como del alma (DOCUMENTOS PARA LA HISTORIA ARGENTINA, tomo XX, 1929, p. 520). 
DOSSIÊ: FONTES E PROBLEMAS COLONIAIS, LEITURAS E ANÁLISES ATUAIS:

TEMAS DA CULTURA SUL-AMERÍNDIA NO CONTEXTO COLONIAL

Ni solo obra nro. Sr estos milagros en las almas destos nuevos Xpiânos, sino también en los cuerpos. Fue un padre a visitar un enfermo i hállale con el pecho ia hinchado i para rendir el alma; supo no avía recibido el viatico. Tomolo el doliente [...] con mucha fe i devoción; mostro lo el efecto porque luego se sintió mejor y el día siguiente sanó del todo (DOCUMENTOS PARA LA HISTORIA ARGENTINA, tomo $X X, 1929$, p. 314).

Se as justificativas para o emprego de licores, relíquias e orações parecem se resumir à "debil medicina"; a atuação como "medicos no solo de sus cuerpos, pero también de sus almas" encontra respaldo nos sucessos extraordinários e nos relatos edificantes de conversão:

[...] también con los pocos remedios que acá ay procuramos curarlos porque ellos no tienen medicinas ni hacen remedios sino dejasen morir. El año pasado dio una enfermedad de catarro de que enfermo caso todo el pueblo y el padre Juan de Salas les hizo un jarabe con que sanaron casi todos aunque algunos murieron [...] aunque algunos les vino tanta abundancia de flemas que no las pudo vencer tan débil medicina y otras que a habido (DOCUMENTOS PARA LA HISTORIA ARGENTINA, tomo XX, 1929, p. 88).

[...] pero poco a poco se van desengañando, y viendo con sus ojos los indios como los nros les son verdaderos padres dando-les con amor de tales cuanto piden como lo haya en casa, y siéndoles médicos no solo de sus almas q es lo principal, sino de sus cuerpos ayudándoles en todas sus enfermedades y trabajos de noche y de día (DOCUMENTOS PARA LA HISTORIA ARGENTINA, tomo XX, 1929, p. 24).

Acreditamos, no entanto, que as expressões "con que se van aficionando a las cosas de nra. Santa fe", "q. Dios le había sanado por medio del Sto. baptismo" e "con mucha fe i devoción", além de revelarem a estreita relação entre cura e conversão estabelecida pelos padres, apontam para a possível razão da aceitação das práticas curativas cristãs-europeias pelos indígenas: a magia de que se revestiam e que as aproximava da tradicional terapêutica indígena. 
DOSSIÊ: FONTES E PROBLEMAS COLONIAIS, LEITURAS E ANÁLISES ATUAIS:

TEMAS DA CULTURA SUL-AMERÍNDIA NO CONTEXTO COLONIAL

Acreditando numa certa predestinação para atuarem como médicos dos corpos e das almas dos indígenas, os missionários chegavam, inclusive, a descuidarem de sua própria saúde em tempos de peste, confiantes que estavam numa presumida imunidade diante do inevitável contágio:

Mientras tanto se declaró una epidemia que hizo gran estrago. [...] El contagió se hizo tan general en la ciudad que prostró también a todos los sacerdotes, menos a los de la Compañía, para que pudiesen asistir a los moribundos. No hicieron solamente esto, sino repartieron medicinas para los enfermos, y limosnas a los pobres (DOCUMENTOS PARA LA HISTORIA ARGENTINA, tomo XX, 1929, p. 523).

Pelo que pudemos apurar na documentação, a resistência ao uso da farmacopeia e da terapêutica indígena disponíveis não se restringia ao tratamento dos indígenas, podendo ser também observada no tratamento das enfermidades dos próprios missionários, como fica claro na Informação sobre a Redução de Nra. Sra. De la Natividad del Acarayg:

Yo avía mas de mes i medio que lo estaba de tiriçia [...] e el Pe Claudio con su gran caridad hizo una chozuela con unos cueros [...] i allí cobre alguna mejoría, mas con las oraciones / las oraciones del Pe que con otro remedio, que no le avía, ni regalo ninguno [...] (DOCUMENTOS PARA LA HISTORIA ARGENTINA, tomo XX, 1929, p. 294).

O registro em destaque atesta, ainda, a crença na intercessão divina e na eficácia das orações, coerente com a percepção de doença e de cura dos missionários, que não só consideravam natural invocar a ajuda de Deus como também recebiam com naturalidade a punição ou a misericórdia divina. A compreensão de que as pestes se constituíam em manifestação da cólera divina, e em castigo para aqueles que não se mantinham firmes na fé, pode ser constatada nesta passagem que transcrevemos:

[...] con estas cosas parece q. suficientemente nos había ayudado el Señor dándonos a entender, que quería el mirar por este pueblo, pero aun más 
DOSSIÊ: FONTES E PROBLEMAS COLONIAIS, LEITURAS E ANÁLISES ATUAIS:

TEMAS DA CULTURA SUL-AMERÍNDIA NO CONTEXTO COLONIAL

claramente nos lo ha manifestado castigando a otros [...] Al oír los indios de los Padres, que semejantes epidemias son instrumentos de la divina justicia, se fueron a ellos rogándoles que organizasen solemnes rogativas para aplacar la ira de Dios... (CARTA ÂNUA [1635 - 1637] apud LEONHARDT, 1927a, p. 702).

Se, por um lado, as epidemias eram consideradas "instrumentos de la divina justicia", o controle ou a minimização de seus efeitos danosos passaram a ser considerados indicativos da proteção divina, garantida através da conduta exemplar dos indígenas. São numerosos os relatos em que os missionários registram os efeitos que estas intervenções divinas - através das pestes ou das curas milagrosas produziam sobre a conduta moral dos indígenas, bem como os múltiplos recursos empregados (procissões, remédios, sangrias, relíquias e confissões) para que epidemias e cataclismos fossem superados:

Los otros días dando una enfermedad, de S. Ignacio se hizo una procesión muy solemne llevando de un pueblo a otro la imagen con que el Sor servido no pasase adelante la peste y en otra dice los indios gras al sor están muy adelante en las cosas de Dios, no ay borracheras ni amancebamtos donde muchos estaban enredados antes en abominables vicios los cuales abominan ahora (DOCUMENTOS PARA LA HISTORIA ARGENTINA, tomo XX, 1929, p. 146).

Cogiese dese trabajo grande fruto con confesiones generales, y mudanzas de vida porque se le ofrecieron a los Pes lances muy venturosos, e hicieron hablar a muchos demonios mudos, que se avían apoderado de los corazones largos años, y tal vez teniendo perdido el habla y aun el sentido se la restituyo nro $\mathrm{Sr}$ milagrosamente para que se confesase tocándole con una milagrosa imagen de nro Pe $S$. Igno [...] (DOCUMENTOS PARA LA HISTORIA ARGENTINA, tomo $X X, 1929$, p. 427).

Cabe ressaltar que as Cartas Ânuas que analisamos constituem-se de relatos edificantes, referindo-se essencialmente aos casos de doentes que se disseram - e se mostraram - curados após a intercessão da invocação aos santos, do uso da água benta e das relíquias, e da 
DOSSIÊ: FONTES E PROBLEMAS COLONIAIS, LEITURAS E ANÁLISES ATUAIS:

TEMAS DA CULTURA SUL-AMERÍNDIA NO CONTEXTO COLONIAL

administração dos sacramentos. Não encontramos, nos registros referentes ao período mencionado, qualquer referência aos insucessos nas tentativas de curas; ou, ainda, menção a recidivas das doenças, o que atestaria que a terapêutica empregada pelo missionário não havia sido eficaz, levando o indígena a repeti-la ou, então, a desacreditá-la.

Deve-se, no entanto, considerar que, tanto a medicina quanto os médicos neste período tinham poucos recursos para descobrir e avaliar as recidivas das doenças, não dispondo, também, de uma terminologia muito rigorosa e de métodos de diagnóstico muito seguros. Muitas das doenças conhecidas no século XVII cediam - ou pareciam ceder mediante o emprego de alguma terapêutica, produzindo facilmente a "ilusão da cura", condição fundamental para o prestígio de um médico ou curandeiro. Considerando que muitos destes procedimentos de cura estavam ligados a substâncias ou rituais mágicos, facilmente se difundiam entre os adoentados e os recém-curados a vinculação entre magia e cura, entre fé e milagre. Mas não apenas as curas foram habilmente manipuladas pelos missionários jesuítas em função do projeto de civilização e conversão dos Guarani. Também as não curas em especial as mortes resultantes das epidemias ou de doenças graves foram instrumentalizadas para difundir novas condutas morais e a crença na salvação da alma, como veremos mais adiante no texto.

A despeito da resistência dos missionários à farmacopeia e às terapêuticas nativas, é preciso considerar que "un solo médico no podía dar atención eficiente a cien mil indios, ni siquiera a la mitad", o que pode ter significado "que las recetas y soluciones indígenas debían ser de uso general" (ECHENIQUE e FERREIRA, 1985, p. 260), o que, com certeza, possibilitou a sobrevivência das práticas curativas xamanísticas, bem como a receptividade às prédicas dos magos. Parece-nos que a contestação e perseguição que os missionários empreenderam aos xamãs não devem ser compreendidas como uma condenação das ervas, poções e bálsamos empregados nas curas, mas como um repúdio à mística envolvida nessas curas e aos rituais mágicos que garantiam sua eficácia. Daí ser possível perceber o confronto entre xamãs e missionários como uma disputa de saberes e poderes, pelo controle das doenças e pela manipulação das curas e não curas. 


\section{DOSSIÊ: FONTES E PROBLEMAS COLONIAIS, LEITURAS E ANÁLISES ATUAIS:}

TEMAS DA CULTURA SUL-AMERÍNDIA NO CONTEXTO COLONIAL

$\mathrm{Na}$ medida em que não propriamente os recursos medicinais sofreram contestação, mas sim sua eficácia ritual, os registros feitos pelos padres jesuítas, ao longo do século XVII, revelam uma apropriação cada vez maior da farmacopeia americana (ervas, resinas e folhas); bem como adaptações da terapêutica tradicional empregada pelos indígenas, como nos casos dos ferimentos expostos e das otites e conjuntivites decorrentes da varíola. É em razão disso que se pode afirmar que medicina praticada nas reduções jesuíticas "unió al ingrediente mágico el recurso a los remedios vegetales", já que, por iniciativa dos missionários-boticários, foram identificadas diversas plantas medicinais e seus usos para incorporação no sistema médico tradicional, com base na medicina humoral "por la cual cada medicamento tenía una cualidad, fría, cálida, seca o húmeda y un grado de exponente del uno al cuatro" (TÉLLEZ, 1993, p. 20)12.

Apesar dos inúmeros registros que referem uma medicina que uniu concepções, recursos e procedimentos nas reduções, em alguns como no do Pe. Provincial Andres de Rada, do ano de 1663 - se constata a manutenção da atribuição da cura de índios atingidos por uma epidemia à ingestão de água "tocada con cierta esquela":

El pueblo de Santa María sufría mucho por cruel peste [...] Y todavía no se veía mengua del contagio, cuando se les ocurrió a los Padres, combatirlo de un modo. Estaba a la mano un libro, recién publicado, del Padre Juan Eusebio (intitulado Opera Parthenical). Líalo uno de los Padres y en el séptimo opúsculo, epist 10, pág 409 , encontró que a muchos era saludable remedio agua tocada con cierta esquela con la inscripción: In conceptione tua, Virgo immaculata fueste. Ora pro nobis Deum, cujus filium pereriste. iCosa maravillosa! Se tomaba el agua con aquella esquela, y al instante amainó aquella calamidad, tanto que nadie fue atacado por la epidemia, y los postrados en cama para esperar su último instante, recobraron sus fuerzas y sanaron

\footnotetext{
${ }^{12}$ Conforme Téllez: "Esta patología humoral que pasó a las tierras conquistadas por España, fue curiosamente introducida, más que por médicos o boticarios, por los misioneros y el clero en general, que eran quienes en realidad asistían a los enfermos tanto en los hospitales como en los lugares más remotos, llevando a los indios además de su fe, un nuevo concepto de medicina. Los misioneros, hombres educados en las doctrinas de su tiempo, conocedores de las lenguas y la literatura clásicas y en contacto directo con el pueblo, fueron, pues, el vehículo adecuado para la difusión de la medicina humoral" (TÉLLEZ, 1993, p. 22).
} 
DOSSIÊ: FONTES E PROBLEMAS COLONIAIS, LEITURAS E ANÁLISES ATUAIS:

TEMAS DA CULTURA SUL-AMERÍNDIA NO CONTEXTO COLONIAL

(CARTA ÂNUA [1663-1666] apud LEONHARDT, 1927d, p. 102).

Mesmo em obras de caráter médico, como a Opera Parthenical, do Pe. Juan Eusebio, persistem as práticas curativas de caráter mágico. Dentre as possíveis razões para a manutenção e divulgação dessas práticas, ganha relevo a que está associada à mudança que se operava nas condutas dos indígenas e ao "cambio de sus sentimientos" decorrentes das curas milagrosas, através das quais "tan supersticiosa gente, se trocó en cristiana y de una fe tenacísima" (EUSEBIO apud MAEDER, 1984, p. 80). Buscando exatamente esse efeito - o crescente "aprovechamiento en la fe y costumbres cristianas" (EUSEBIO apud MAEDER, 1984, p. 147) -, os missionários mantiveram o uso de relíquias, da água benta e das orações nas reduções, pela crença que os indígenas tinham em sua eficácia.

Independentemente dos sucessos obtidos com o emprego da "magia eclesiástica" e das "experiências medicinais", os missionários "sabían muy bien sus limitaciones y por eso se preocuparon cuanto antes, traer de Europa hombres especializados en la ciencia médica" (FURLONG apud ECHENIQUE e FERREIRA 1985, p. 258). Esta preocupação se materializou na solicitação de envio de médicos, enfermeiros e boticários às missões, encaminhada ao Padre Geral da Companhia de Jesus, em 1632. Isto explica por que, apesar das dificuldades em compreender e aceitar as práticas rituais da terapêutica indígena e das restrições à farmacopeia indígena, os herbários e boticários das Missões Jesuíticas serão admirados por cronistas e historiadores como Azara, Lozano e Guevara13.

No século XVIII, caberia aos Padres Pedro de Montenegro e Segismundo Asperger a organização de importantes catálogos das ervas medicinais e suas aplicações, sendo esses jesuítas os pioneiros na utilização da "farmacopeia indígena" e nas adaptações feitas à

\footnotetext{
${ }^{13}$ Bertoni (1927) chama a atenção para a importância da farmacopeia indígena para as inovações da medicina moderna: "La creencia de que el conocimiento de las plantas medicinales de estos países se deba principalmente a los Padres Jesuítas, es bastante generalizada en el público de estos países. Sin embargo, es inexacta. Es indudable que los Jesuítas hicieron mucho; pero fue en el sentido de recoger las informaciones de los Indios, someterlos al crisol de la experiencia, y transmitirlas" (BERTONI, 1927, p. $382)$.
} 
DOSSIÊ: FONTES E PROBLEMAS COLONIAIS, LEITURAS E ANÁLISES ATUAIS: TEMAS DA CULTURA SUL-AMERÍNDIA NO CONTEXTO COLONIAL

europeia ${ }^{14}$. Ao mencionar uma epidemia de varíola, ocorrida em 1719, e que teria dizimado dezessete mil índios, Pedro Arata informa que

[...] el padre Segismundo Asperger parte con los remedios traídos de Europa y parte con las yerbas medicinales del país, cuyas virtudes y propiedades conocía muy bien [...] había libertado de la muerte un gran número de personas [...] (ARATA, 1898, p. 443).

Também Azara, referindo-se ao Padre Asperger, registra que "el hizo mil ensayos con todas las plantas, que es el medio de hallar específicos, y no el que usan en Europa valiéndose siempre de lo que hay en la botica[...]" (ARATA, 1898, p. 443).

O crescente emprego da farmacopeia indígena na cura de determinadas doenças não só ampliou as possibilidades de manipulação das curas pelos missionários, como reduziu, significativamente, o caráter depreciativo atribuído à mesma. Além disso, revela que, conscientes dos efeitos que as curas e a "boa morte" exerciam sobre os indígenas, os jesuítas não hesitaram em adotar estratégias de apropriação criativa e bricoladora (CERTEAU, 1994, p. 39-40) que garantissem a devoção e a piedade cristãs almejadas.

Para tanto, contribuiu, sem dúvida, a percepção, tanto dos missionários quanto dos indígenas, de que as doenças resultavam de intervenções sobrenaturais decorrentes de transgressão moral ou religiosa, e que para afastá-las ou garantir a proteção divina, deveriam ser empregados procedimentos terapêuticos e rituais que envolviam cânticos, orações, procissões, exorcismos e práticas mágicas. Da mesma forma, os Guarani - valendo-se de seus "modos de percepção e intelecção" - buscaram salvaguardar as manifestações tradicionais de sua espiritualidade, através de procedimentos de apropriação seletiva e criativa - como fica demonstrado na ressignificação do chorar copioso e dos lamentos fúnebres -, que, ao viabilizar o projeto reducional,

\footnotetext{
${ }^{14}$ De acordo com Arata (1898), "Los historiadores del Rio de la Plata (Lozano, Guevara, etc.), los viajeros (Azara, Demersay, Martin de Moussy, etc.) hablan todos con admiración unas veces, y con curiosidad e interés siempre de los Herbarios de las Plantas Medicinales de Misiones hechos por los padres jesuitas y transmitidos manuscritos de reducción en reducción, de convento en convento. [...] Los curanderos de la época colonial y aun nuestros médicos viejos, les atribuían grande importancia, a tal punto que se copiaban y volvían a copiar sigilosamente" (ARATA, 1898, p. 430-431).
} 
DOSSIÊ: FONTES E PROBLEMAS COLONIAIS, LEITURAS E ANÁLISES ATUAIS:

TEMAS DA CULTURA SUL-AMERÍNDIA NO CONTEXTO COLONIAL

conformaram de maneira peculiar a sensibilidade religiosa das reduções jesuítico-guarani.

\section{A morte e o morrer - das práticas tradicionais às reducionais}

De acordo com a antropóloga Branislava Susnik (1983), os indígenas sul-americanos não manifestam medo da morte, mas um profundo medo dos mortos, e, sobretudo, das almas dos mortos que colocavam em perigo as almas dos parentes vivos (SUSNIK, 1983, p. 54). Este comportamento foi também observado entre os Araweté, para os quais "os mortos povoam o discurso cotidiano, a história e a geografia", e a morte constitui-se em "acontecimento que põe em movimento, literalmente, a sociedade e a pessoa Araweté" (VIVEIROS DE CASTRO, 1986, p. 56). Entre estes indígenas

o período que se segue à morte de um adulto é extremamente perigoso [...] o medo que se abate violentamente sobre todos, após o enterro [...] contrasta de modo visível com a ostensiva 'profissão de indiferença' por ocasião do momento da morte e de exposição do cadáver. [...] tão logo o cadáver sai de cena a indiferença dá lugar a um mal contido pânico, e a inércia à pressa (VIVEIROS DE CASTRO, 1986, p. 491).

Para os Guarani, a morte era percebida como um fenômeno puramente natural, resultante de más ações, tendo sua origem mítica explicada na conduta de Jasy (Lua) que impediu que Kuarahy ressuscitasse sua mãe (BARTOLOMÉ, 1977, p. 79). À morte eram atribuídas causas naturais e antinaturais. A morte por causas naturais ocorria

cuando el hombre o la mujer ya pasan al status de 'ancianos', carentes de 'fuerza vital', que no cazan ni desempeñan tareas propias para la subsistencia del grupo doméstico, y cuya alma encuéntrase en un estado de 'vagancia external' (SUSNIK, 1983, p. 54).

Por outro lado, a morte era considerada antinatural quando estivesse 
DOSSIÊ: FONTES E PROBLEMAS COLONIAIS, LEITURAS E ANÁLISES ATUAIS:

TEMAS DA CULTURA SUL-AMERÍNDIA NO CONTEXTO COLONIAL

associada a poderes sobrenaturais ou à magia negra praticada pelos xamãs (SUSNIK, 1983, p. 54). Estes, em razão disso, eram percebidos pelos indígenas como seres temíveis, capazes de realizar feitiços e de destruir seus inimigos a léguas de distância. Tal poder fez com que fossem considerados como "os mais sérios obstáculos à cristianização [...] os autênticos sequazes de Satanás" pelos missionários (CLASTRES, 1975, p. 35-36).

Entre estes mesmos indígenas, as práticas rituais funerárias, além de assegurarem a separação da alma do corpo morto, previam a expressão pública da dor, lamento e ira (SUSNIK, 1990, p. 103). O Pe. Antônio Ruiz de Montoya, em Carta Ânua de 1628, registrou a forma como os Guarani enterravam seus mortos, considerando-a "ignorançias y abusos":

[...] enterram seus defuntos no campo, fazendo sobre a sepultura [...] de quando em quando limpam a erva que nasce sobre ela e dizem que o fazem para que descanse o defunto. Outros enterram o defunto em casa para tê-los por companhia. Ao tempo de enterrar o defunto cortar o panos e as cordas que prendem as barracas em que os enterram para que não morram outras pessoas da mesma casa [...] (MANUSCRITOS DA COLEÇÃO DE ANGELIS, tomo I, 1951, p. 274).

Dentre as formas usuais de sepultamento entre os Guarani, Susnik destaca a prática do enterro em urnas: "se enterraba directamente el cadáver, pero en este caso, la fosa se calafeteaba com ramas para evitar el contacto directo del cuerpo con la tierra, y se erigía una choza funeraria en miniatura" (SUSNIK, 1990, p. 113). Quanto à duração do luto, a antropóloga afirma que este compreendia um período que se estendia de

un a seis meses según el grado de parentesco con el muerto; las mujeres suelen visitar la tumba para cumplir con el ritual de lamentaciones, se reincorporan a la vida normal, cuando a las mujeres vuelven a crecer los cabellos y a los hombres cubren la tonsura frontal hasta la altura de los ojos (SUSNIK, 1990, p. 113). 
DOSSIÊ: FONTES E PROBLEMAS COLONIAIS, LEITURAS E ANÁLISES ATUAIS:

TEMAS DA CULTURA SUL-AMERÍNDIA NO CONTEXTO COLONIAL

O já referido Pe. Antonio Ruiz de Montoya, em sua obra Conquista Espiritual, de 1639, registrou o seguinte costume em relação ao luto: "A la muerte del marido las mujeres se arrojan de estado medio de alto, dando gritos, y a veces suelen morir de aquestos golpes o quedar lisiadas" (MONTOYA, 1989, p. 78). O missionário observou também que:

Em cada parte destas regiões costuma haver usos particulares e assim, mesmo que o chorarem a seus defuntos seja coisa comum em todos e com mais intensidade quanto aos mais nobres, aqui acrescentavam o de desnudar-se uma mulher $e$, tomando ela um arco e setas, sair às ruas, para atirálas na direção do sol: o que vem a ser um sinal de raiva que têm à morte, que com o desejo intentam matar. Procuram os padres evitar tais ações, por inconvenientes, mas não era possível nem lícito fazê-lo com insistência, visto tratar-se de gente nova na fé (MONTOYA, 1985, p. 222).

De acordo com Vara(h), os Guarani "tienen como sustrato la creencia en la reencarnación" e que "sobre todo los huesos son considerados esenciales para obtener una resurrección, o reencarnación inmediata del individuo"; e, ainda, que "los grandes shamanes son considerados capaces, con sus rezos, de provocar tal acontecimiento" (VARA(H), 1984, p. 114). Estes, com suas rezas, acompanhavam "el alma divina del sujeto hacia la morada de la deidad que lo envió" (VARA(H), 1984, p. 113). Também a antropóloga Branislava Susnik refere

la crencia de que el alma vital del muerto acompaña el cuerpo al sepulcro, aunque separado de él, libre de su receptáculo corporal, emprendiendo recién después de un tiempo su viaje al más allá; se la separación anímica no es violenta, las almas están apegadas al mundo de los vivos (SUSNIK, 1990, p. 113).

Numa referência a essas crenças, o Pe. Montoya observa que os indígenas "julgavam que a alma acompanhava o morto ao sepulcro, mas separada do corpo", o que fazia com que muitos "enterrassem os mortos em urnas, pondo um prato em sua abertura, para que as almas nelas ficassem acomodadas" (MONTOYA, 1989, p. 78). Referindo-se à mesma crença, Susnik esclarece que 
el "alma" del difunto quedaba "enterrada" con el cuerpo, lo que significaria un peligro potencial para los vivos; la "convivencia" del alma con el cuerpo significaria un "poder" perturbador; según el concepto de los Guaraníes, el alma, separada del cuerpo, es libre, externada, para "trasladarse" al lugar post-mortem y de esta manera no apeligrando ya el mundo de los vivos (SUSNIK, 1983: 67).

Em razão disso, torna-se compreensível a resistência que os indígenas mostraram à adoção do enterro cristão, na medida em que "La muerte significa la separación de la identidad anímica del hombre de su receptáculo corporal; pero, lo anímico es para los primitivos siempre una potencia existente, transformable" (SUSNIK, 1983, p. 67)15. A crença na ressurreição e o culto aos ossos entre os Guarani são descritos por Montoya:

O demônio procura remedar em todas as partes o culto divino com ficções e embustes [...] Numa das reduções estávamos sofrendo uma grande dificuldade [...] até que um moço revelou a um padre [...] que em três cerros havia três corpos de mortos, os quais falavam e haviam dito aos índios que não dessem ouvidos às pregações dos padres. [...] Deu também o informe de que era voz corrente terem ressuscitado esses três índios [...] $\mathrm{E}$, subindo com enorme custo ao cume daquele monte, descobriram um templo, em, que eram honrados aqueles ossos secos. Recolheram os padres os ossos, junto com as suas plumas e ornatos, e levaram tudo isso (MONTOYA, 1985, p. 104-105).

É oportuno lembrar que os procedimentos adotados pelos missionários nas reduções foram normatizados através das Instruções do Pe. Diogo de Torres, que estabeleciam que os enterros dos índios deveriam ser feitos "com solenidade, usando o padre sobrepeliz, estola

\footnotetext{
${ }^{15}$ Sobre a reação dos Guarani ao enterro cristão, Susnik observa: "En los primeros tiempos, los Guaranises reaccionaban al entierro cristiano; agitaban el adazo sobre la tumba, tratando de liberar el alma que creían encerrada, aprisionada con el cuerpo en la tumba cristiana. [...] Y las urnas resguardaban los huesos, el potencial asiento del alma. En su lucha contra da cristianización, los gayráes antiguos desenterraban los huesos de los shamanes muertos, colocándolos en hamaca y cubriendo con el manto plumario; creían que sus almas volvían a tomar 'su sede' en los huesos y hablar como oráculos" (SUSNIK, 1990, p. 113).
} 
DOSSIÊ: FONTES E PROBLEMAS COLONIAIS, LEITURAS E ANÁLISES ATUAIS:

TEMAS DA CULTURA SUL-AMERÍNDIA NO CONTEXTO COLONIAL

e cruz [...] o cortejo deveria ser seguido pelos acólitos, que rezando e cantando como manda a Santa Igreja, acompanhavam o padre até a casa do defunto" (PASTELLS, 1912, p. 352-353).

As alterações introduzidas no ritual funerário, decorrentes tanto da administração dos sacramentos do batismo, da extrema-unção ou do viático quanto da determinação do local da sepultura e do enterro à maneira cristã, podem ser observadas nos registros do Pe. Montoya:

Numa peste de varíola adoeceu certo moço [...] Tive o
desejo de que sua vida o Senhor ma conservasse. Na
véspera de sua morte fui visitá-lo e, vendo-o muito
perto do fim, disse-lhe que desejava eu sua saúde,
mas que devíamos conformar-nos com a vontade
divina. Disse-me ele a isso:
Padre, acabo agora de visitar o Santíssimo
Sacramento, e Nosso Senhor me deu a entender que
tenho de morrer muito em breve. Estou muito
consolado e desejoso de que se cumpra sua vontade
(MONTOYA, 1985, p. 76) ${ }^{16}$.

A aceitação da vontade divina e a resignação diante da revelação da morte iminente pelos indígenas apontariam, segundo Montoya, para a assimilação de condutas próprias do Cristianismo. A Ânua referente aos anos de 1641 a 1643, ao registrar o sepultamento de uma indígena, parece atestar esta percepção do missionário: "[...] a puseram em um caixão feito para esta finalidade que foi levado pelos caciques principais e pelos capitães [...] o ritual foi acompanhado de canto e órgão, tendo sido enterrada no altar maior, com grande solenidade [...]" (CARTA ÂNUA [1641-1643] apud MAEDER, 1996, p. 120).

Nesta mesma Carta Ânua, encontramos referência às missas em intenção das almas dos defuntos, o que revelaria - na perspectiva dos missionários - outro aspecto da assimilação mencionada, pois os indígenas já demonstravam "grande apreço aos sacramentos e às missas em intenção dos seus país e mães já falecidos com a solenidade que

\footnotetext{
${ }^{16}$ Nas reduções, segundo Meliá, o enterro ocorria ao final da tarde, sendo que o cortejo fúnebre era acompanhado de "rezos y cantos de los músicos, pero también 'desentonados' lamentos de indias viejas antigua costumbre que muchos años de misión no han podido desarraigar - y en los que lloran y elogian al difunto por lo que ha sido y ha hecho o al menos por lo que hubiera podido hacer y hubiera podido ser, de haber seguido viviendo" (MELIÀ, 1986, p. 207).
} 
DOSSIÊ: FONTES E PROBLEMAS COLONIAIS, LEITURAS E ANÁLISES ATUAIS:

TEMAS DA CULTURA SUL-AMERÍNDIA NO CONTEXTO COLONIAL

permite sua pobreza" (CARTA ÂNUA [1641-1643] apud MAEDER, 1996, p. 79).

Também os registros de batismo a moribundos parecem apontar para esta assimilação, como neste caso em que uma mãe, ao pressentir a morte do filho recém-nascido, o batiza, sugerindo a associação entre o sacramento do batismo e a garantia da vida eterna:

Claramente o mostrou uma mulher cristã, que, tendo dado à luz e percebendo sinais de morte em seu bebê recém-nascido, bem como não havendo quem lhe chamasse o padre, levou-o ela mesma à fonte de batismo. Lá, logo depois de purificar-se, a criança voou aos céus, ficando sua mãe contentíssima por haver dado vida imortal a quem, se tardasse mais uns instantes, teria morrido à vista de Deus para sempre (MONTOYA, 1985, p. 194).

Igualmente significativo é o registro em que, na percepção dos missionários, aparece enunciada a relação que os indígenas estabeleceram entre pecado - morte e perdão - céu:

Oculta e torpemente vivia certa mulher, sendo disso apenas testemunha uma filhinha sua de dois anos, cuja pouca idade lhe tirava qualquer receio de sua culpa [...] Mas a menininha mostrou-se ofendida por pecado tão grande, chegou a repreender respeitosamente sua mãe lasciva e Ihe disse: Eu quero morrer, para não ter de presenciar as tuas desonestidades. Emenda-te, pois hei de solicitar no céu o teu perdão! (MONTOYA, 1985, p. 205).

Nesse caso, sem dúvida, a consciência da desonestidade cometida pela mãe, atribuída a uma criança de dois anos, deve ser considerada como produto da interpretação do Pe. Montoya. De qualquer forma, a relação entre conduta honesta e perdão remete à atribuição de responsabilidade moral, representada no relato pelas advertências que a criança teria feito à mãe. Esse episódio, com o relato do manifesto desejo de morrer da criança, foi explorado pelo missionário, que o revestiu de tons edificantes.

As Cartas Ânuas que analisamos revelam, ainda, que, no contexto reducional, o "bem morrer" pressupunha o batismo, a confissão e a 
DOSSIÊ: FONTES E PROBLEMAS COLONIAIS, LEITURAS E ANÁLISES ATUAIS:

TEMAS DA CULTURA SUL-AMERÍNDIA NO CONTEXTO COLONIAL

recepção dos sacramentos da extrema-unção ou viático. A passagem a seguir revela esta percepção, ao relatar que uma defunta foi amortalhada e que o tempo que deveria ser guardado antes do enterro na Igreja havia sido respeitado:

[...] a batizei e depois de um tempo, seu espírito foi ao Criador. Mas antes de enterrá-la, orientei-os a que a velassem por um tempo assim amortalhada como estava, pois tinham o costume de enterrar os mortos tão logo expiravam. Agora aguardam o tempo que é necessário (DOCUMENTOS PARA LA HISTORIA ARGENTINA, 1929, p. 504).

Um registro feito ao final do século XVII permite dimensionar as alterações introduzidas pelos missionários jesuítas em relação aos rituais funerários, através da referência aos andores, ao cortejo, à mortalha e às louvações. Através desse relato percebe-se a normatização que cercava os rituais fúnebres, destinada a introduzir procedimentos sucedâneos de práticas rituais anteriores, como na clara referência à substituição das "lamentações fúnebres", no cortejo para a Igreja, pela louvação a Deus.

As mãos do marceneiro aprontaram há dias o andor para enterros de inocentes, que uma prematura morte faz voar ao céu. Os carregadores destes cadáveres inocentes são igualmente seis pequenos inocentes. Para estes mandei fazer trajes novos, bordados de flores e franjas. Com igual brilho resplandece almofada sobre a qual reclina o feliz defunto, bem como mortalha branca que o cobre. No caminho para a igreja, em lugar das lamentações fúnebres, os músicos cantam um peã vitorioso, convidando os jovens e as donzelas a louvarem a Deus (SEPP, 1980, p. 240-241).

Nas reduções - de acordo com os registros dos padres jesuítas -, as expressões da sensibilidade guarani diante da morte assumiram uma uniformidade e publicidade bastante distantes das espontâneas manifestações originais. Ilustrativa neste sentido é a passagem que extraímos das Ânuas referentes aos anos de 1632 a 1634, e que descrevem tanto os ritos guarani que envolviam o luto e o sepultamento 
DOSSIÊ: FONTES E PROBLEMAS COLONIAIS, LEITURAS E ANÁLISES ATUAIS:

TEMAS DA CULTURA SUL-AMERÍNDIA NO CONTEXTO COLONIAL

quanto as demonstrações de sentimento e de devoção tidas como aceitáveis e estimuladas pelos missionários.

Tinham muito arraigado o bárbaro costume de chorar supersticiosamente e intensamente os seus defuntos ao uso gentílico, de sorte que em tempo de peste não se ouvia outra coisa pelo povoado a não ser lúgubres lamentos [...] todos eram convidados a fazer coro sobre o defunto, desfazendo-se em choro por dias e noites. Corrigiram os padres este costume, introduzindo demonstrações de sentimentos cristãos e de piedade com os defuntos, fazendo com que ao dobre dos sinos se juntem mais de mil almas que acompanham o cortejo para dar sepultura ao morto. E todos cantam e rezam com muita devoção e compostura as orações na Igreja (CARTA ÂNUA [1632 - 1634] apud MAEDER, 1990, p. 37).

A descrição de um funeral que consta da Ânua do período de 1672 a 1675 - decorridos já mais de 60 anos de atuação missionária junto aos indígenas - destaca, no entanto, a manutenção de traços do cerimonial guarani tradicional17:

Aumentou, todavia, o apreço pela religião entre os bárbaros como atesta a solenidade com que a criatura morta foi conduzida à sepultura na igreja por um caminho coberto de flores e por arcos triunfais feitos de ramas de árvores em procissão solene. Contemplavam com curiosidade os bárbaros aquelas cerimônias fúnebres cristãs porque estes índios procedem muitas vezes de outro modo com os seus, em um cego gentilismo (CARTA ÂNUA [1672 - 1675] apud LEONHARDT, 1927e, p. 34-35).

As frequentes referências às "demostraciones de sentimientos" pelos indígenas ganham projeção nesta passagem que trata da morte de um missionário, ocasião em que, segundo o relator, se observou "un lastimoso alarido" e "un funestisimo llanto".

Os índios, ao saberem da morte do padre pelo dobre dos sinos, cercaram sua casa e iniciaram um lastimoso alarido, no que foram seguidos pelos índios que se

\footnotetext{
${ }^{17} \mathrm{Cf}$. nota anterior.
} 
DOSSIÊ: FONTES E PROBLEMAS COLONIAIS, LEITURAS E ANÁLISES ATUAIS:

TEMAS DA CULTURA SUL-AMERÍNDIA NO CONTEXTO COLONIAL

encontravam espalhados nas rancherías do povoado e assim se continuou a ouvir as demonstrações de sentimento, através dos gritos e dos prantos, como se fossem aqueles dias confusos que antecedem o juízo final (CARTA ÂNUA [1632-1634] apud MAEDER, 1990, p. 48).

Este registro permite a inferência de que o "chorar copioso", manifestação nitidamente vinculada a uma encenação ritual tradicional entre os Guarani, assumiu aos olhos dos missionários a condição de resultante da consciência de culpabilidade e demonstração pública de arrependimento, como fica atestado nestes trechos da Ânua de 1632 1634:

Mas o padre, penetrando brandamente em seus corações através de amorosas palavras, fez com que caíssem em si, e que saíssem daquele transe com muita penitência e lágrimas. Assim acabaram todos se confessando e agradecendo pela infinita misericórdia divina (CARTA ÂNUA [1632-1634] apud MAEDER, 1990, p. 71).

Predicando por "inspiración sensible", os missionários instavam os indígenas a sentirem "el remordimiento de su conciencia", o que tinha, segundo eles, efeitos surpreendentes sobre as condutas dos indígenas. Isto pode ser observado nesta passagem da Ânua de 1659-1662:

Certo dia, um homem ao ouvir a pregação de um dos padres contra o crime da hipocrisia e da ocultação dos pecados na confissão, sentiu tanto arrependimento que não conseguiu se conter, passando a manifestar-se através de prantos e gritos. Em seguida, entre torrentes de lágrimas, pôs-se a listar os seus pecados. Ajoelhou-se diante do seu confessor e, entre muitos soluços e banhado em lágrimas, Ihe entregou as três folhas de papel, quase desmaiando de tanta dor e arrependimento (CARTA ÂNUA [1659 - 1662] apud LEONHARDT, 1927c, p. 77).

Expressões como "bañado en lágrimas", "con lágrimas de dolor y arrepentimiento" e "torrentes de lágrimas" são usadas de forma recorrente na documentação jesuítica para ressaltar a assimilação pelos 
DOSSIÊ: FONTES E PROBLEMAS COLONIAIS, LEITURAS E ANÁLISES ATUAIS:

TEMAS DA CULTURA SUL-AMERÍNDIA NO CONTEXTO COLONIAL

indígenas das expressões da piedade e da devoção tridentinas. Cremos, no entanto, que a assimilação a que se referem os missionários aponta mais uma vez para a ressignificação das manifestações tradicionais de sentimentos de emoção individual e coletiva dos indígenas guarani. Vale ressaltar que, em outras situações, o costume da "saudação lacrimosa" entre os Guarani é apresentado como manifestação de caridade e comoção próprias dos cristãos:

Esta redução de Loreto não é apenas a mais antiga de todas, como a mais constante no exercício da caridade. [...] Esta se manifestou exemplarmente por ocasião da transmigração de algumas das reduções. Ao se encontrarem, ficaram tão comovidos os indígenas que durante um bom tempo não conseguiram falar, apenas chorar, até que conseguiram se saudar mutuamente segundo $o$ seu próprio costume, abraçando-se efusivamente e distribuindo refrescos e provisões, num espetáculo muito terno (CARTA ÂNUA [1637-1639] apud MAEDER, 1984, p. 93).

\section{Considerações finais}

Como pudemos observar, lágrimas, soluços, gritos e suspiros são referidos nas Ânuas analisadas para ressaltar o nível de comoção e comunhão coletiva alcançado pelos indígenas durante as missas, procissões e festas religiosas. Orientadas e estimuladas pelos missionários, estas manifestações de sensibilidade religiosa registradas nas Ânuas se distanciavam - e muito - daquelas condutas descritas como exteriorização brusca e ruidosa de sentimentos, qualificadas como condenáveis "ignorancias y abusos" nos primeiros registros. Sonhos, visões, curas milagrosas e ressurreições são também referidos pelos missionários com o intuito de ressaltar a intensidade do fervor religioso dos indígenas, expresso na tensão emocional, na atmosfera trágica e no ardor carismático que caracterizavam as missas, procissões e penitências que antecediam os feriados religiosos ou as calamidades anunciadas, como as pestes "que Dios les envía por castigo de sus 
culpas" aos indígenas reduzidos 18 .

A análise revelou, ainda, que os missionários, além de incorporarem a farmacopeia americana e muitas das práticas curativas indígenas, manipularam habilmente as curas e o "bien morir", estratégia que foi fundamental para atrair e manter os Guarani nas reduções. Acreditamos, no entanto, que, se nesse processo de conversão dos Guarani - e que implicou o "viver em redução" - os missionários definiram estratégias e manejaram símbolos, os resultados estiveram condicionados às motivações e às aspirações dos indígenas. Tomados como indícios da adesão aos valores cristãos e como demonstração pública da interiorização e assimilação da "civilização dos afetos e da conduta" pretendida pelos missionários, estes comportamentos e práticas constituíram-se, na verdade, em expressão da ressignificação da sensibilidade religiosa indígena.

\section{Referências bibliográficas}

ARATA, Pedro. Botânica Médica Americana: Los Herbarios de las Misiones del Paraguay. La Biblioteca, Buenos Aires, v. 2, n. 7, p. 419-448, 1898.

ARRÓSPIDE, José Luís. Antonio Ruiz de Montoya y las reducciones del Paraguay. Asunción: Centro de Estudios Paraguayos Antonio Guasch, 1997.

BAREIRO SAGUIER, Rubén; CLASTRES, Hélène. Aculturación y mestizaje en las Misiones Jesuíticas del Paraguay. Aportes, Paris, n. 4, p. 7-27, out. 1969.

BARRAN, José Pedro. História de la sensibilidad en el Uruguay: la cultura "bárbara" - 1800-1860. Montevideo: Ediciones de la Banda Oriental, 1990.

BARTOLOMÉ, Miguel Alberto. Shamanismo y religión entre los Avá-Katú-Ete del Paraguay. Cidade do México: Instituto Indigenista Interamericano, 1977. (Coleção Antropologia Social, 17).

BERTONI, Moisés Santiago. La civilización guarani. Paraguay: Imprenta y Edición Ex Sylvis, 1927.

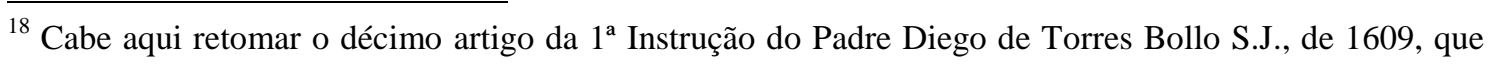
recomendava que somente os fiéis assistissem à missa. Neste caso, a punição dos fiéis omissos ou ausentes se devia ao fato de que poderiam estar potencialmente retornando ao seu "antigo costume", o que poderia comprometer, não só "a fortaleza da fé" de muitos, mas também a conversão futura de outros.
} 
DOSSIÊ: FONTES E PROBLEMAS COLONIAIS, LEITURAS E ANÁLISES ATUAIS:

TEMAS DA CULTURA SUL-AMERÍNDIA NO CONTEXTO COLONIAL

BLOCH, Marc. Os reis taumaturgos. São Paulo: Companhia das Letras, 1993.

CERTEAU, Michel de. A invenção do cotidiano: artes de fazer. Petrópolis: Vozes, 1994.

CERVANTES, Fernando. El diablo en el Nuevo Mundo. Barcelona: Herder, 1996.

CLASTRES, Hélène. Terra sem mal: o profetismo tupi-guarani. São Paulo: Brasiliense, 1975.

DOCUMENTOS PARA LA HISTORIA ARGENTINA (Cartas Ânuas de la Província del Paraguay, Chile y Tucumán de la Província de la Compañía de Jesús - 1615-1637, tomo XX). Buenos Aires: Talleres Casa Jacobo Preuser, 1929.

ECHENIQUE, Nora; FERREIRA Miriam. La medicina en las reducciones jesuíticas. In: SIMPÓSIO NACIONAL DE ESTUDOS MISSIONEIROS, 5., 1985. Santa Rosa. Anais. Faculdade de Filosofia, Ciências e Letras Dom Bosco. p. 235-252.

FURLONG, Guillermo. Misiones y sus Pueblos de Guaraníes. Buenos Aires: Teorema, 1962.

GARLET, Ivori José. Mobilidade Mbyá: História e Signficação. 1997. 322 f. Dissertação (Mestrado em História) - PUC-RS, [1997].

KERN, Arno Alvarez. Missões: Uma Utopia política. Porto Alegre: Marcado Aberto, 1982.

LEONHARdT, Carlos. Cartas Ânuas de la Província del Paraguay [1635-1637]. Buenos Aires: mimeo,1927a. mimeo,1927b.

Cartas Ânuas de la Província del Paraguay [1644]. Buenos Aires:

. Cartas Ânuas de la Província del Paraguay [1659 - 1662]. Buenos Aires: mimeo, $1927 \mathrm{c}$.

Cartas Ânuas de la Província del Paraguay [1663-1666]. Buenos Aires: mimeo,1927d.

. Cartas Ânuas de la Província del Paraguay [1672-1675]. Buenos Aires: mimeo,1927e.

LÉVI-STRAUSS, Claude. Antropologia estrutural. Buenos Aires: Eudeba, 1968.

MAEDER, Ernesto J. A.(Org.). Cartas Ânuas de la Provincia del Paraguay, 1637 - 
DOSSIÊ: FONTES E PROBLEMAS COLONIAIS, LEITURAS E ANÁLISES ATUAIS:

TEMAS DA CULTURA SUL-AMERÍNDIA NO CONTEXTO COLONIAL

1639. Buenos Aires: FECIC, 1984.

. (Org.). Cartas Anuas de la Provincia del Paraguay, 1632 - 1634. Buenos Aires: FECIC, 1990.

(Org). Cartas Ânuas de la Província Jesuítica del Paraguay, 1641-1643.

Resistência: Instituto de Investigaciones Geohistoricas, 1996. (Coleção Geohistoria Regional, 11).

MANUSCRITOS DA COLEÇÃO DE ANGELIS - Tomo I. Rio de Janeiro: Biblioteca Nacional, 1951. (Jesuítas e Bandeirantes no Guairá (1549 - 1640).

MELIÀ, Bartomeu. El Guarani: Conquistado y Reducido. Asunción: Biblioteca Paraguaya de Antropologia, 1986.

MÉTRAUX, Alfred. La causa y el tratamiento mágico de las enfermedades entre los índios de la región tropical sud-americana. América Indígena, Cidade do México, v. 4, n. 2, p. 157-164, 1944.

MONTOYA, Antonio Ruiz de. Conquista Espiritual. Porto Alegre: Martins Livreiro, 1985.

La Gran “Conquista Espiritual” del Paraguay. Rosário: Equipo Difusor de Estudios de Historia Iberoamericana, 1989.

Vocabulário y Tesoro de la Lengua Guarani / Arte y Bocabulário de la Lengua Guarani. Viena/Paris: Faesy y Frick/Maisonneuve, 1876.

PASTELlS, Pablo. História de la Compañía de Jesús en la del Provincia Paraguay. Madrid: Librería General de Victoriano Suarez, 1912. v. $1 .$.

RÍPODAS ARDANAZ, Daisy. Movimientos shamanicos de liberación. Teologia, Buenos Aires, v.24, n. 50, p. 245-252, 1987.

SEPP, Antonio S.J. Viagem às Missões Jesuíticas e Trabalhos Apostólicos. Belo Horizonte/São Paulo: Editora Itatiaia/Editora da Universidade de São Paulo, 1980.

SUSNIK, Branislava. Los aborígenes del Paraguay: ciclo vital y estructura social. Asunción: Museo Etnográfico Andres Barbero, 1983.

Cultura Religiosa I (ambito americano). Asunción: Manuales del Museo Etnográfico Andres Barbero, 1989.

Guerra, trânsito, subsistencia. Asunción: Manuales del Museo Etnográfico Andres Barbero, 1990. 
DOSSIÊ: FONTES E PROBLEMAS COLONIAIS, LEITURAS E ANÁLISES ATUAIS:

TEMAS DA CULTURA SUL-AMERÍNDIA NO CONTEXTO COLONIAL

TÉLlEZ, Carmen Sánchez. La medicina en las lenguas americanas y filipinas prehispánicas. Madrid: Producciones Gráficas de la Universidad de Alcalá de Henares, 1993.

VARA(h), Alfredo. La construcción guaraní de la realidad: una interpretación psicoanalítica. Asunción: Centro de Estudios Antropológicos/Universidad Católica, 1984.

VIANNA, Hélio. Jesuítas e Bandeirantes no Uruguay (1611 - 1758): Manuscritos da Coleção De Angelis. Rio de Janeiro: Biblioteca Nacional, 1970. v. 4.

VIVEIROS DE CASTRO, Eduardo. Araweté: os deuses canibais. Rio de Janeiro: Jorge Zahar Ed., 1986. 